\title{
A Comparative Study on a Cationic Dye Removal through Homogeneous and Heterogeneous Fenton Oxidation Systems
}

\author{
Shima Rahim Pouran, ${ }^{1, \star}$ Abolfazl Bayrami, ${ }^{2}$ Mohammad Saleh Shafeeyan, ${ }^{3, \star}$ \\ Abdul Aziz Abdul Raman ${ }^{4}$ and Wan Mohd Ashri Wan Daud ${ }^{4}$ \\ ${ }^{1}$ Research Laboratory of Advanced Water and Wastewater Treatment Processes, Department of Applied Chemistry, \\ Faculty of Chemistry, University of Tabriz, 51666-16471 Tabriz, Iran. \\ ${ }^{2}$ Department of Biology, Faculty of Science, University of Mohaghegh Ardabili, Ardabil, Iran. \\ ${ }^{3}$ Department of Chemical and Materials Engineering, Buein Zahra Technical University, Qazvin, Iran. \\ ${ }^{4}$ Chemical Engineering Department, Faculty of Engineering, University of Malaya, 50603 Kuala Lumpur, Malaysia. \\ *Corresponding author: E-mail: rahimpooran@yahoo.com (S. Rahim Pouran), \\ ms.shafeeyan@gmail.com (M.S. Shafeeyan)
}

Received: 03-08-2017

\begin{abstract}
Oxidative treatment of a cationic dye solution, methylene blue, was investigated using magnetite nanoparticles and goethite in heterogeneous Fenton-like reaction, and ferrous ions in homogeneous Fenton-reaction. The aim was to compare the degradation efficiencies of the studied catalysts for decolorization of methylene blue solution as the model organic pollutant. Response surface methodology (RSM) was applied to determine the optimal operational conditions for magnetite $/ \mathrm{H}_{2} \mathrm{O}_{2}$ and goethite $/ \mathrm{H}_{2} \mathrm{O}_{2}$ systems. The $\left[\mathrm{H}_{2} \mathrm{O}_{2}\right]$ of $0.2 \mathrm{M}$, catalyst dosage of $1 \mathrm{~g} / \mathrm{L}, \mathrm{pH} 9.0$ and reaction time of $5 \mathrm{~h}$ were chosen by RSM. The $\mathrm{pH}$ value of 3.0 was used in the case of $\mathrm{Fe}^{+2} / \mathrm{H}_{2} \mathrm{O}_{2}$ system. The experimental results showed that homogeneous Fenton oxidation system was the most effective system under both acidic and neutral conditions but decreased at $\mathrm{pH}$ value of 9.0 due to the decrease in available $\mathrm{Fe}^{2+}$ ions in the solution and generation of ferric hydroxide sludge. $\mathrm{Fe}_{3} \mathrm{O}_{4} / \mathrm{H}_{2} \mathrm{O}_{2}$ system represented better removal efficiency than $\mathrm{FeO}(\mathrm{OH}) / \mathrm{H}_{2} \mathrm{O}_{2}$ system that could be attributed to the presence of $\mathrm{Fe}^{2 \mathrm{II}}$ cations in magnetite structure and its larger surface area.
\end{abstract}

Keywords: Heterogeneous Fenton, Response surface methodology, Magnetite nano-particles, Goethite

\section{Introduction}

Tones of synthetic dyes are produced universally due to their wide applications in many industries, especially textiles. Since dyes are considered as one of the severe environmental pollutants, a large number of studies were opened to minimize their impact on human health and the environment. ${ }^{1-6}$ Advanced oxidation processes (AOPs) are among the most accepted treatment methods for removal of dyes and pigments. The generation of highly reactive species is the key factor for effective decomposition of organic pollutants through AOPs. Fenton reaction has attracted considerable attention due to its simple equipment, ease of operation and higher efficiency. ${ }^{7-10}$ In this reaction, the catalytic activity of iron species leads to $\mathrm{H}_{2} \mathrm{O}_{2}$ breakdown into highly reactive hydroxyl radicals (Eq. 1):

$$
\mathrm{H}_{2} \mathrm{O}_{2}+\mathrm{Fe}^{2+} \rightarrow \mathrm{Fe}^{3+}+{ }^{-} \mathrm{OH}+{ }^{\circ} \mathrm{OH}
$$

There are large numbers of studies on Fenton treatment of various industrial wastewaters and synthetic solutions at laboratory or pilot plant scales. ${ }^{11}$ Fenton treatment of synthetic dye solutions such as Alizarin red S dye (C.I. 58005), ${ }^{12}$ Acid Blue 193 and Reactive Black 39, ${ }^{13}$ C.I. Basic Red 46 (BR46), ${ }^{14}$ and C.I. Acid Red 14 azo dye, ${ }^{15}$ are number of the examples reported in literature. In conventional Fenton reaction, using iron salts $\left(\mathrm{Fe}^{2+}\right.$ and $\mathrm{Fe}^{3+}$ ions), due to the availability of the reactants in the reaction solution, the degradation rate is high and under the optimal condition, and decolorization occurs within a short reaction time. However, this reaction is effective only at acidic condition of $\mathrm{pH} 3.0$, while the soluble iron is precipitated as ferric hydroxide at higher $\mathrm{pH}$ conditions, resulting in the 
catalyst withdrawal from the reaction medium. Accordingly, the catalyst recovery is also impracticable. In light of this, a number of solutions have been proposed to overcome the shortcomings of homogeneous Fenton reaction. Application of chelating agents, ${ }^{11}$ and heterogeneous catalysts, ${ }^{11,16}$ are examples to stabilize the iron in the solution and expand the applicable $\mathrm{pH}$ range of the reaction. Large numbers of heterogeneous iron compounds such as zero-valent iron (ZVI), ${ }^{17}$ clays, silica, zeolites, ${ }^{18}$ and iron minerals, ${ }^{16}$ have been studied for dye wastewater treatment through Fenton reaction. In heterogeneous catalysts, iron is fixed in the structure and activates the reaction over broad range of $\mathrm{pH}$ (Eq. 2). In addition, it can be simply separated from the solution by magnet or filtering.

$$
\equiv \mathrm{Fe}_{\text {saf }}^{2+}+\mathrm{H}_{2} \mathrm{O}_{2} \rightarrow \equiv \mathrm{Fe}_{\text {saf }}^{3+}+\mathrm{OH}^{-}+{ }^{\circ} \mathrm{OH}
$$

In the present study, magnetite and goethite were chosen for heterogeneous Fenton treatment of synthetic $\mathrm{MB}$ wastewater. Methylene blue (MB) was selected as the model dye pollutant because of its extensive application in textile industry and recalcitrant nature. Central composite design (CCD) was used to optimize the Fenton-like reactions. The main objective of this study was to assess the efficiency of Fenton reaction catalyzed by magnetite nanoparticles and goethite as heterogeneous catalysts. In addition, the decolorization efficiencies of the studied heterogeneous catalysts were compared with homogeneous Fenton under various $\mathrm{pH}$ conditions.

\section{Experimental}

\section{1. Chemicals}

All the chemicals were of reagent grade and used without further purification. Catalase $(10,000-40,000$ units/mg protein), magnetite $\left(\mathrm{Fe}_{3} \mathrm{O}_{4}\right)$ and goethite $\left(\mathrm{HFeO}_{2}\right)$ were purchased from Sigma Aldrich. Methylene blue (MB), Hydrogen peroxide $\left(\mathrm{H}_{2} \mathrm{O}_{2}, 30 \% \mathrm{w} / \mathrm{w}\right)$, Ferrous sulfate $\left(\mathrm{FeSO}_{4} 7 \mathrm{H}_{2} \mathrm{O}\right)$, Sodium hydroxide $(\mathrm{NaOH})$ and Sulfuric acid $\left(\mathrm{H}_{2} \mathrm{SO}_{4}\right)$ were purchased from Merck. The ferrous $\left(\mathrm{Fe}^{2+}\right)$ catalyst was prepared by dissolving $\mathrm{FeSO}_{4}$ in distilled water and was used immediately to avoid the rapid oxidation of $\mathrm{Fe}^{2+}$.

\section{2. Homogeneous Fenton Experiments}

Fenton experiments were carried out in batch using a $250 \mathrm{~mL}$ borosilicate glass beaker with $100 \mathrm{~mL}$ of $\mathrm{MB}$ solution at initial pH of $3.0 \pm 0.1$ (known as the optimum $\mathrm{pH}){ }^{19}$ and temperature of $25^{\circ} \mathrm{C}$. The MB solution was acidified using sulfuric acid that was monitored using a Cyber Scan pH meter (Eutech, Thermo Fisher Scientific). Subsequently, a fixed amount of $\mathrm{Fe}^{2+}$ was added and Fenton reaction was initiated by addition of predetermined amount of $\mathrm{H}_{2} \mathrm{O}_{2}$ solution under constant magnetic stirring to homogenize the mixture. ${ }^{11}$ At the end of the stipulated time period, the $\mathrm{pH}$ was readjusted to $10.0 \pm 0.5$, leading to reaction termination. The residual $\mathrm{H}_{2} \mathrm{O}_{2}$ was removed from the solution using a few drops of catalase enzyme (10 $\mathrm{V} / \mathrm{V}) .{ }^{20} \mathrm{~A} 0.22 \mu \mathrm{m}$ Millipore filter was used to remove the ferric hydroxide precipitate before the remnants of the $\mathrm{MB}$ concentration was monitored. Prior to the measurement, a calibration curve was obtained using standard MB solutions with known concentrations. The following equation (Eq.3) was used to calculate the percentages of color removal:

$$
\text { Color removal }(\%)=\frac{\left(\mathrm{X}_{0}-X_{i}\right)}{X_{0}} \times 100
$$

where, $\mathrm{X}_{0}$ is the initial value of color $(\mathrm{mg} / \mathrm{L})$ and $\mathrm{Xi}$ is the measured value of color $(\mathrm{mg} / \mathrm{L})$ after defined reaction time. The reaction was repeated at $\mathrm{pH} 7.0 \pm 0.1$ to assess the effectivity at neutral condition and at $\mathrm{pH} 9.0 \pm 0.1$. The measurements were done at least in duplicate and the results were expressed as mean values of the measurements with an experimental error below 5\%.

\section{3. Heterogeneous Fenton Experiments}

The MB degradation studies by nano-magnetite and goethite samples were carried out in a batch system at $25^{\circ} \mathrm{C}$. The initial pH of the dye solution was adjusted to 9.0 using $\mathrm{NaOH}$ solution. A predetermined amount of each sample was added to dye solution $(50 \mathrm{mg} / \mathrm{L})$ and constantly stirred mechanically at $170 \mathrm{rpm}$ for $60 \mathrm{~min}$, to achieve sorption equilibrium. Then, depending on the experimental design, $0.1-0.3 \mathrm{~mol} / \mathrm{L} \mathrm{H}_{2} \mathrm{O}_{2}$ was added to solutions to initiate Fenton reaction. After $300 \mathrm{~min}$, the catalyst particles were separated from the solution by centrifugation at $3500 \mathrm{rpm}$ for $5 \mathrm{~min}$ and the equilibrium concentration of $\mathrm{MB}$ was determined by a UV-Vis spectrophotometer (Spectroquant ${ }^{\circ}$ Pharo 300) at $\lambda_{\max } 664 \mathrm{~nm}$ using Eq. (3). The experiments were repeated at $\mathrm{pH} 7.0 \pm 0.1 \mathrm{using} 1 \mathrm{~g} / \mathrm{L}$ of each sample and $0.2 \mathrm{~mol} / \mathrm{L} \mathrm{H}_{2} \mathrm{O}_{2}$ (optimum values) to assess the efficiency at neutral condition.

\section{4. Design of Experiments (DOE)}

Design Expert Software (version 9.0.3) was used for the statistical design of experiments, development of regression models, data analysis and optimization of Fenton-like reactions. Response surface methodology (RSM) was employed to assess the individual and interactive effects of two independent variables: (A) $\mathrm{H}_{2} \mathrm{O}_{2}$ and (B) catalyst concentrations on color removal efficiencies (\%) of both hetero-catalysts. For both catalysts, a face centered CCD that consists of 4 factorial points, 4 axial points and 3 replicates at the center points were applied. The center points were used to estimate the experimental error and the duplicability of the data. The ranges between $0.1-0.3$ 
mol/L for $\left[\mathrm{H}_{2} \mathrm{O}_{2}\right], 0.5-1.5 \mathrm{~g} / \mathrm{L}$ for catalysts concentration and oxidation reaction time of $300 \mathrm{~min}$ were chosen based on the preliminary studies and the literatures. ${ }^{21-23}$

A total of 11 experiments were performed for each hetero-catalyst in which three of them were at the center point: $(\mathrm{A})=0.2,(\mathrm{~B})=1$. The following second order polynomial equation (Eq. 4) was used to predict the studied variable factors as a function of independent variables and the interaction among them:

$$
Y=b_{0}+\sum_{i=1}^{k} b_{i} X_{i}+\sum_{i=1}^{k} b_{i i} X_{i}^{2}+\sum_{i=1}^{k} \sum_{j=1}^{k} b_{i j} X_{i} X_{j}+\varepsilon
$$

where, $\mathrm{Y}$ is the predicted dependent variable, $\mathrm{b}_{0}$ is constant coefficient, $b_{i}, b_{i i}$ and $b_{i j}$ are regression coefficients, $i$ and $j$ are index numbers, $k$ is number of patterns, $X_{i}$ and $X_{i}$ are independent variables and $\varepsilon$ is the random error. ${ }^{24}$ The analysis of variance (ANOVA) was used to assess the significance and adequacy of the model. The fitness of the polynomial models was expressed by the coefficients of determination, $\mathrm{R}^{2}, \mathrm{R}_{\text {adj }}^{2}$ and $\mathrm{R}_{\text {pred }}^{2}$. The main indicators that were used to show the significance of the model were Fisher variation ratio (F-value), probability value (Prob $>\mathrm{F}$ ) with $95 \%$ confidence level and adequate precision. The final model for each response was obtained after elimination of insignificant terms $(p>0.05)$ based on F-test and the 3-D plots were presented. Furthermore, the optimum values for independent variables were identified and further experiments were performed to verify the regression models. ${ }^{25-26}$

\section{Results and Discussion 3. 1. Experimental Design and ANOVA Analysis}

Table 1 presents the results obtained from the heterogeneous Fenton experiments for the magnetite and goethite catalyzed reactions.
Two quadratic models were proposed to describe the color removal efficiencies through Fenton catalyzed by magnetite and goethite (Eqs. 5 and 6):

Magnetite:

Color removal $(\%)=+50.00000+4.64912 \times$ catalys $t+$ $79.91228 \times \mathrm{H}_{2} \mathrm{O}_{2}+35.00000 \times$ catalyst $\times \mathrm{H}_{2} \mathrm{O}_{2}-$

\section{$3.15789 \times$ catalyst $^{2}$}

Goethite:

Color removal $(\%)=+50.73333+7.93333 \times$ catalyst + $13.33333 \times \mathrm{H}_{2} \mathrm{O}_{2}+30.00000 \times$ catalyst $\times \mathrm{H}_{2} \mathrm{O}_{2}-$

\section{$4.10000 \times$ catalyst $^{2}$}

In these equations, the positive and negative symbols signify the synergistic or antagonistic effects respectively. Analysis of variance (ANOVA) was performed to evaluate the "goodness of Fit" of the proposed models. The results of ANOVA for both catalysts are given in Table 2 . From the results, the p-values of both catalysts for the studied response were less than $0.05(<0.0001$ and 0.0002$)$ that shows the models were significant and could be used for prediction of the studied response. Furthermore, in order to assess the quality of the equations, regression coefficients of $\mathrm{R}^{2}$, adjusted $\mathrm{R}^{2}$ and predicted $\mathrm{R}^{2}$ were used. The closeness of $\mathrm{R}^{2}$ values to 1.00 showed that the models were highly reliable regarding experiments repetition. The values obtained for magnetite and goethite were respectively $\mathrm{R}^{2}: 0.98$ and 0.99 , Adj $\mathrm{R}^{2}: 0.97$ and 0.98 and Pred $\mathrm{R}^{2}: 0.87$ and 0.95 that showed the significance of the models to predict the studied response. The difference less than 0.2 between pred- $\mathrm{R}^{2}$ and adj- $\mathrm{R}^{2}$ indicates a good agreement in the results for both catalysts.

Moreover, the results for adequate precision (the ratio of signal to noise) were 25.162 and 37.337 that were much greater than the required value of 4.0. This shows

Table 1. Experimental Design Matrix and Response for Magnetite and Goethite

\begin{tabular}{ccccc}
\hline Run No. & A: catalyst $(\mathrm{g} / \mathrm{L})$ & B: $\mathbf{H}_{2} \mathbf{O}_{2}(\mathbf{m o l} / \mathrm{L})$ & \multicolumn{2}{c}{ Color removal $(\%)$} \\
Magnetite & Goethite \\
\hline 1 & & & 68 & 63 \\
2 & 1 & 0.2 & 67 & 64 \\
3 & 1 & 0.2 & 59 & 56 \\
4 & 0.5 & 0.1 & 74 & 71 \\
5 & 1.5 & 0.3 & 61 & 59 \\
6 & 1.5 & 0.1 & 67 & 63 \\
7 & 1 & 0.2 & 64 & 60 \\
8 & 0.5 & 0.2 & 62 & 59 \\
9 & 1 & 0.1 & 69 & 65 \\
10 & 1.5 & 0.2 & 65 & 62 \\
11 & 0.5 & 0.3 & 69 & 67 \\
\hline
\end{tabular}


Table 2. Analysis of variance (ANOVA) results for magnetite and goethite

\begin{tabular}{|c|c|c|c|c|c|}
\hline Source & $\begin{array}{c}\text { Sum } \\
\text { of squares }\end{array}$ & $\begin{array}{c}\text { Degrees } \\
\text { of freedom }\end{array}$ & $\begin{array}{l}\text { Mean } \\
\text { square }\end{array}$ & $F$-value & $\begin{array}{c}p \text {-value } \\
(\text { Prob }>\text { F })\end{array}$ \\
\hline \multicolumn{6}{|c|}{ Magnetite } \\
\hline Model & 180.07 & 5 & 36.01 & $63.46 \ldots$ & ......0.0002 \\
\hline Residual & 2.84 & 5 & 0.57 & .......... & .............. \\
\hline Lack of Fit & 2.17 & 3 & 0.72 & $2.717 \ldots$ & ......0.3308 \\
\hline Pure Error & 0.67 & 2 & 0.33 & .......... & ............... \\
\hline Cor Total & 182.91 & 16 & & .......... & $\ldots \ldots \ldots .$. \\
\hline \multicolumn{6}{|c|}{ Goethite } \\
\hline Model & 173.19 & 5 & 34.64 & $128.21 \ldots$ & $\ldots .<0.0001$ \\
\hline Residual & 1.35 & 5 & 0.27 & .......... & ............. \\
\hline Lack of Fit & 0.68 & 3 & 0.23 & $0.68 \ldots .$. & .......0.6395 \\
\hline Pure Error & 0.67 & 2 & 0.33 & ......... & $\ldots \ldots \ldots . .$. \\
\hline Cor Total & 174.55 & 10 & & .......... & ............. \\
\hline
\end{tabular}

an acceptable signal and demonstrates that the models could navigate the design space. On the other hand, the lack of fit values for both hetero-catalysts were not significant that is the satisfactory result for the proposed models because it implies the models were fit to predict the amount of decolorization within the studied range of variables. $^{27}$

\section{2. Optimized Condition}

The optimal conditions for heterogeneous Fenton reactions were obtained by design expert software. The condition proposed for both catalysts were [Catalyst] $1 \mathrm{~g} / \mathrm{L}$, $\left[\mathrm{H}_{2} \mathrm{O}_{2}\right] 0.2 \mathrm{~mol} / \mathrm{L}$, at $\mathrm{pH} 9$ and reaction time of $300 \mathrm{~min}-$ utes. This condition was chosen based on the "maximum" color removal while using "in range" values of Fenton reagents. The color removal (\%) of 67.32 and 63.37 were predicted by software at optimum values for magnetite and goethite catalyzed Fenton reactions respectively. The predicted values were in very close agreement with experimental values by deviation errors less than $0.1 \%$ that indicates the developed models can correlate the amount of catalyst and hydrogen peroxide to decolorization (\%) with high accuracy.

\section{3. Effects of the Fenton Reagents on Decolorization Efficiency}

The effects of the initial concentrations of $\mathrm{H}_{2} \mathrm{O}_{2}$ and the hetero-catalysts on decolorization efficacy are shown in Fig. $1 \mathrm{a}$ and $1 \mathrm{~b}$.

As can be seen in the graphs, the increase in $\mathrm{H}_{2} \mathrm{O}_{2}$ concentration was favored for decolorization in both catalysts. This is due to the generation of sufficient amount of - $\mathrm{OH}$ radicals. However, when the amount of $\mathrm{H}_{2} \mathrm{O}_{2}$ exceeded up to $0.3 \mathrm{~mol} / \mathrm{L}$, the efficiency decreased due to the ${ }^{\circ} \mathrm{OH}$ scavenging effects of $\mathrm{H}_{2} \mathrm{O}_{2}$ (Eq. 7) that leads to the genera-
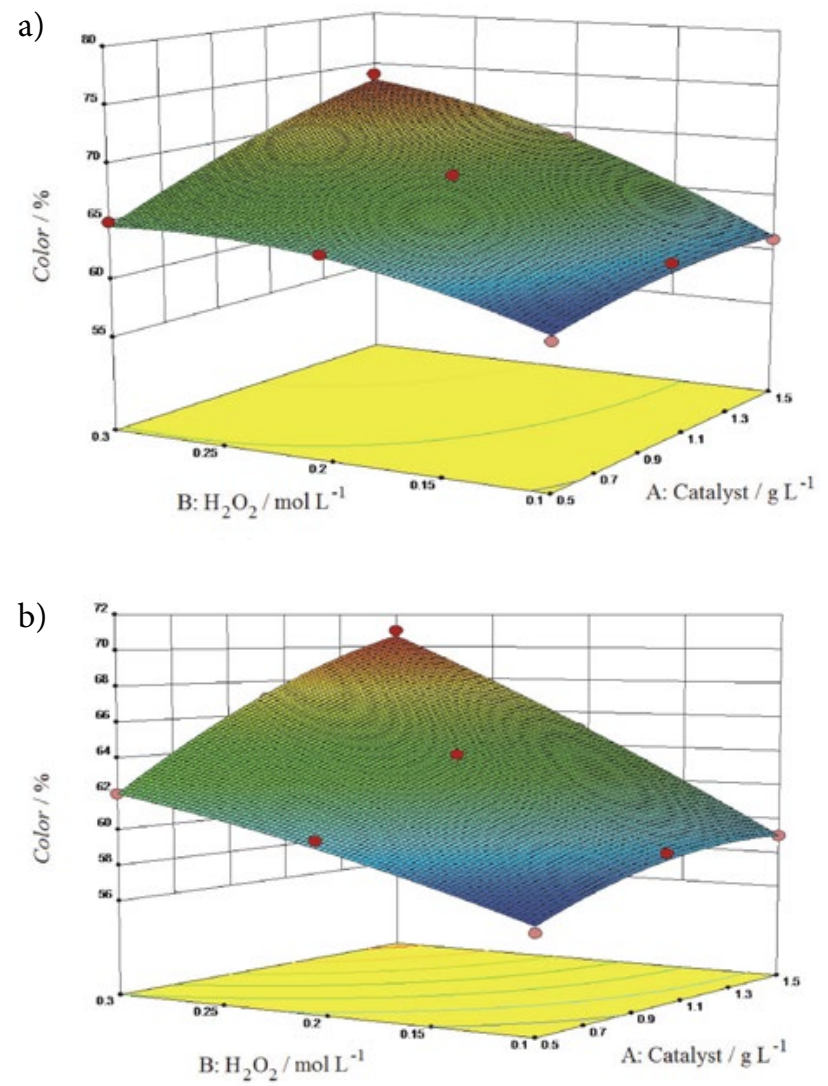

Fig 1. The 3-D response surface of the effect of catalyst and $\left[\mathrm{H}_{2} \mathrm{O}_{2}\right]$ on color removal (\%) using (a) nano-magnetite and (b) goethite in Fenton-like reaction

tion of hydroperoxyl radical $\left(\mathrm{HO}_{2}{ }^{\circ}\right) . \mathrm{HO}_{2} \cdot$ radicals are relatively less active than ${ }^{\circ} \mathrm{OH}$ radicals and also lead to a further decline in ${ }^{\circ} \mathrm{OH}$ availability in reaction solution as shown in Eq. (8):

$$
\mathrm{H}_{2} \mathrm{O}_{2}+\mathrm{OH} \rightarrow \mathrm{H}_{2} \mathrm{O}+\mathrm{HO}_{2}^{*}
$$




$$
\mathrm{HO}_{2}^{\cdot}+{ }^{\circ} \mathrm{OH} \rightarrow \mathrm{H}_{2} \mathrm{O}+\mathrm{O}_{2}
$$

Similarly, higher concentrations of both catalysts resulted in higher removal efficiencies when appropriate amount of $\mathrm{H}_{2} \mathrm{O}_{2}$ was available in the reaction medium. It is worth noting that in heterogeneous catalysis, adsorption of the probe molecule on the surface of the catalyst plays a critical role in degradation reaction where the degradation occurs on the surface of the catalyst. To achieve this, there should be an interaction between the catalyst surface and the pollutant molecules. For this, one of the main surface characteristics that should be considered is the point of zero charge $\left(\mathrm{pH}_{\mathrm{pzc}}\right)$ of the employed catalysts. The $\mathrm{pH}_{\mathrm{pzc}}$ is a $\mathrm{pH}$ value that the surface of the catalyst is neutral. The surface is acidic at $\mathrm{pH}$ values below $\mathrm{pH}_{\mathrm{pzc}}$ and is basic at $\mathrm{pH}$ values above $\mathrm{pH}_{\mathrm{pzc}}$. Since, methylene blue is a cationic dye, it is attracted toward the surface at $\mathrm{pH}>$ $\mathrm{pH}_{\mathrm{pzc}}$. The $\mathrm{pH}_{\mathrm{pzc}}$ of magnetite and goethite are 6.0-6.8 and $7.4-8.2$, respectively. ${ }^{22}$

Therefore, the $\mathrm{pH}$ value of 9 was chosen in present study as optimum value to increase the adsorption of $\mathrm{MB}$ on the surface of the both hetero-catalysts.

On the other hand, the experiments were carried out at $\mathrm{pH} 7$ to assess the decolorization effectiveness of the employed catalysts at neutral condition and under the optimum concentrations of Fenton reagents. As explained earlier, the $\mathrm{pH}_{\mathrm{pzc}}$ of the magnetite is less than 7, thus $\mathrm{MB}$ adsorbed on its surface and resulted in accelerated color removal. However, the removal efficiency at $\mathrm{pH} 7$ was less than $\mathrm{pH}$ 9. On the contrary, there was no adsorption of $\mathrm{MB}$ on the surface of goethite at $\mathrm{pH}<\mathrm{pH}_{\mathrm{pzc}}$ due to electrostatic repulsions between the cationic dye molecules and positively charged surface of goethite. Accordingly, the decolorization rate decreased below $10 \%$.

\section{4. Comparison Between Homogeneous and Heterogeneous Processes}

In order to compare the effectiveness of the heterogeneous Fenton process with homogeneous reaction, a set of experiments were conducted with soluble iron under the same optimized Fenton reagents, with varying $\mathrm{pH}$ conditions of 3 (optimal value for homogeneous reaction), 7 and 9. The color of MB solution immediately disappeared under the studied condition with $\mathrm{pH} 3$. Under neutral condition, although, much of the soluble iron was precipitated as ferric hydroxide, still the decolorization rate was much higher than heterogeneous process in which $\mathrm{MB}$ degradation was accomplished within a minute. This was because the amount of used soluble iron for degradation of $50 \mathrm{ppm} \mathrm{MB}$ was higher than the required amount. Similar trend was observed at $\mathrm{pH} 9$ but degradation process took longer time of about $25 \mathrm{~min}$.

Since, there is no mass transfer limitation in homogeneous reaction; the amount of utilized Fenton reagents in heterogeneous reaction was much higher than that of required for homogeneous reaction. On this basis, the Fenton reagents concentrations decreased 10 times and additional experiments were carried out using $\left[\mathrm{Fe}^{2+}\right] 0.1$ $\mathrm{g} / \mathrm{L}$ and $\left[\mathrm{H}_{2} \mathrm{O}_{2}\right] 0.02 \mathrm{~mol} / \mathrm{L}$ at $\mathrm{pH} 3,7$ and 9. Comparatively, very fast decolorization was observed at $\mathrm{pH} 3$. At neutral condition, despite of ferric hydroxide generation, $\mathrm{MB}$ removal was completed within a few minutes. In contrast, it took about $15 \mathrm{~h}$ to remove $85 \%$ of color at $\mathrm{pH} 9$.

Although, homogeneous Fenton represented significantly higher removal efficiencies over a short reaction time, the generated sludge is an important issue that should be addressed; especially for treatments at large scales. In addition, to attain complete mineralization of pollutant, acidification of the neutral or basic wastewaters is required. Moreover, the catalyst is not recoverable. ${ }^{30} \mathrm{In}$ contrast, in heterogeneous reaction, the iron oxides could be simply separated from the solution by magnet and reused for several runs with inconsiderable decrease in their efficiency. ${ }^{31}$ In light of this, future studies should focus on production of new heterogeneous catalysts that not only overcome homogeneous Fenton shortcomings but activate Fenton reaction effectively.

\section{Conclusion}

In this study, two iron oxides, nano-magnetite and goethite, were used in Fenton-like degradation of a cationic dye in aqueous solution. The heterogeneous reactions were designed by CCD and the optimized values of [catalyst] 1 $\mathrm{g} / \mathrm{L}$ and $\left[\mathrm{H}_{2} \mathrm{O}_{2}\right] 0.2 \mathrm{~mol} / \mathrm{L}$ were established by software. The color removal efficiencies of $67 \%$ and $63 \%$ were obtained at pH 9 and over 300 minutes by magnetite and goethite catalyzed Fenton reactions, respectively. The comparative studies between heterogeneous and homogeneous Fenton reactions revealed the effectiveness of homogeneous Fenton with significantly lower Fenton reagents (up to 10 times) and higher reaction rate at acidic and neutral condition. However, at basic condition, the degradation efficiency decreased and ferric hydroxide precipitated. Acceptable degradation efficiency at neutral condition along with easier catalyst recovery and reuse make magnetite as a potential solution to prevail the inconveniences accompanied homogeneous Fenton reaction. However, future work in this field should put emphasis on modification in magnetite structure to increase its activity in Fenton reaction and the rate of pollutant degradation.

\section{References}

1. A. Török, E. Buta, C. Indolean, S. Tonk, L. Silaghi-Dumitrescu, C. Majdik, Acta Chim. Slov. 2015, 62, 452-461.

DOI:0.17344/acsi.2014.1109

2. S. T. Ong, H. Y. Gan, L. E. Leow, Acta Chim. Slov. 2017, 64, 144-158. DOI:10.17344/acsi.2016.2983 
3. W. Anku, S. O. B. Oppong, S. K. Shukla, P. P. Govender, Acta Chim. Slov. 2016, 63, 380-391. DOI:10.17344/acsi.2016.2385

4. T. Jerič, R. J. M. Bisselink, W. van Tongeren, A. M. Le Marechal, Acta Chim. Slov. 2013, 60, 666-672.

5. S. Rahim Pouran, A. Bayrami, A. R. Abdul Aziz, W. M. A. Wan Daud, M. S. Shafeeyan, Comprehensive study on the influence of molybdenum substitution on characteristics and catalytic performance of magnetite nanoparticles, Res. Chem. Intermed. 2018, In press.

6. M. R. D. Khaki, M. S. Shafeeyan, A. A. A. Raman, W. M. A. W. Daud, J. Environ. Manage. 2017, 198, 78-94.

7. M. Strlič, J. Kolar, V. S. Šelih, D. Kočar, B. Pihlara, Acta Chim. Slov. 2003, 50, 619-632.

8. A. Žgajnar Gotvajn, J. Zagorc-Končan, Acta Chim. Slov. 2005, 52, 131-137.

9. J. Malešič, J. Kolar, M. Strličb, S. Polanc, Acta Chim. Slov. 2006, 53, 450-456.

10. S. Rahim Pouran, A. Bayrami, A. R. Abdul Aziz, W. M. A. Wan Daud, M. S. Shafeeyan, J. Mol. Liq. 2016, 222, 1076-1084.

11. S. Rahim Pouran, A.R. Abdul Aziz, W.M.A. Wan Daud, J. Indust. Eng. Chem. 2015, 21, 53-69.

DOI:10.1016/j.jiec.2014.05.005

12. C. V. dos Santos Allan, C. Masini Jorge, Talanta 2009, 77, 1081-1086. DOI:10.1016/j.talanta.2008.08.006

13. I. Arslan-Alaton, G. Tureli, T. Olmez-Hanci, J. Photochem. Photobiol. 2009, 202, 142-153.

DOI:10.1016/j.jphotochem.2008.11.019

14. A. R. Khataee, M. Zarei, L. Moradkhannejhad, Desalination 2010, 258, 112-119. DOI:10.1016/j.desal.2010.03.028

15. A. Aleboyeh, N. Daneshvar, M. B. Kasiri, Chem. Eng. Process. Process Intensif. 2008, 47, 827-832.

DOI:10.1016/j.cep.2007.01.033

16. S. Rahim Pouran, A. A. Abdul Raman, W. M. A. Wan Daud, J. Clean. Product. 2014, 64, 24-35.
DOI:10.1016/j.jclepro.2013.09.013

17. I. Grčić, S. Papić, K. Žižek, N. Koprivanac, Chem. Eng. J. 2012, 195-196, 77-90. DOI:10.1016/j.cej.2012.04.093

18. S. Navalon, M. Alvaro, H. Garcia, Appl. Catal. B, 2010, 99, 1-26. DOI:10.1016/j.apcatb.2010.07.006

19. F. J. Rivas, F.J. Beltrán, O. Gimeno, J. Frades, J. Agricult. Food chem. 2001, 49, 1873-1880. DOI:10.1021/jf001223b

20. W. Liu, S. A. Andrews, M. I. Stefan, J. R. Bolton, Water Res. 2003, 37, 3697-703. DOI:10.1016/S0043-1354(03)00264-1

21. J. Rodriguez-Chueca, A. Mediano, M. P. Ormad, R. Mosteo, J. L. Ovelleiro, Water Res. 2014, 60, 250-258.

DOI:10.1016/j.watres.2014.04.040

22. D. B. Hasan, S. R. Pouran, A. A. A. Aziz, S. M. Nashwan, W. M. A. W. Daud, M. G. Shaaban, J. Indust. Eng. Chem. 2015, 25, 186-191. DOI:10.1016/j.jiec.2014.10.033

23. A. Houshmand, W. M. A. Wan Daud, M. S. Shafeeyan, Bull. Chem. Soc. Jpn. 2011, 84, 1251-1260.

24. M. S. Shafeeyan, A. Houshmand, A. Arami-Niya, H. Razaghizadeh, W. M. A. Wan Daud, Bull. Korean Chem. Soc. 2015, 36, 533-538.

25. A. Shamiri, M. S. Shafeeyan, H. C Tee, C. Y Leo, M. K Aroua, N. Aghamohammadi, J. Nat. Gas Sci. Eng. 2016, 35, 605-613.

26. A. Houshmand, W. M. A. W. Daud, M. S. Shafeeyan, Bull. Chem. Soc. Jpn. 2011, 84, 1251-1260.

DOI:10.1246/bcsj.20110145

27. A. Arami-Niya, W. M. A. W. Daud, F. S. Mjalli, F. Abnisa, M. S. Shafeeyan, Chem. Eng. Res. Design 2012, 90, 776-784. DOI:10.1016/j.cherd.2011.10.001

28. C. Appel, L. Q. Ma, R. D. Rhue, E. Kennelle, Geoderma 2003, 90, 77-93. DOI:10.1016/S0016-7061(02)00316-6

29. B. H. Diya’uddeen, S. Rahim Pouran, A. R. Abdul Aziz, W. M. A. W. Daud, RSC Adv. 2015, 5, 68159-68168.

30. S. Rahim Pouran, A. R. Abdul Aziz, W. M. A. Wan Daud, M. S. Shafeeyan, RSC Adv. 2015, 5, 87535-87549.

\section{Povzetek}

Narejena je bila primerjava učinkovitosti dveh postopkov razbarvanja raztopine barvila metilen modro s Fentonovo oksidacijo: heterogena reakcija $\mathrm{z}$ nanodelci magnetita in geotita ter homogena reakcija z železovimi ioni. Za določitev optimalnih pogojev v sistemu magnetit/ $\mathrm{H}_{2} \mathrm{O}_{2}$ in goetit/ $\mathrm{H}_{2} \mathrm{O}_{2}$ je bila uporabljena RSM metoda, ki je dala reakcijske pogoje: 0,2 $\mathrm{M}\left[\mathrm{H}_{2} \mathrm{O}_{2}\right]$, koncentracija katalizatorjal $\mathrm{g} \mathrm{L}^{-1}, \mathrm{pH} 9,0$ in reakcijski čas $5 \mathrm{~h}$. V sistemu $\mathrm{Fe}^{+2} / \mathrm{H}_{2} \mathrm{O}_{2}$ je razbarvanje potekalo pri $\mathrm{pH}$ 3,0. Eksperimentalni rezultati kažejo, da je homogena Fentonova reakcija najbolj učinkovita $\mathrm{v}$ kislih in nevtralnih pogojih, pri $\mathrm{pH} 9,0$ pa učinkovitost pade zaradi zmanjšanja koncentracije $\mathrm{Fe}^{2+}$ ionov v raztopini in nastanka gošče železovega hidroksida. Sistem $\mathrm{Fe}_{3} \mathrm{O}_{4} / \mathrm{H}_{2} \mathrm{O}_{2}$ je bolj učinkovit od sistema $\mathrm{FeO}(\mathrm{OH}) / \mathrm{H}_{2} \mathrm{O}_{2}$, kar lahko pripišemo prisotnosti FeII kationov v strukturi magnetita in njegovi večji površini. 